\title{
Notes
}

\section{Introduction: The Darwinian Revolution?}

I. That this is still the state of the art was demonstrated in a recent symposium, "Teaching Bio-cultural Anthropology," at the r980 meetings of the American Anthropological Association. All of the participants had tried to teach genuinely integrated biocultural anthropology courses and had found the existing anthropological literature woefully inadequate to the task.

2. This whig view of the history of science has been discussed as it relates to anthropology by George Stocking, Jr., in his Race, Culture, and Evolution (1968).

3. Some of the major works in this school are Barnes 1977; Barnes and Shapin, eds., I979; and Wallis, ed., I979.

4. See, for example, Young 197 I, I 973.

5. Superb examples of this tradition are to be found in various general essays, such as Geertz r $973 a$ and r973b.

6. There are many examples of this approach. One typical study is Murdock 1965 .

7. Mayr has discussed this point at length ( 1982 ). 


\section{Part I Major Western Views of Nature}

\section{Humoral/Environmental Theories and the Chain of Being}

I. Relevant and extremely helpful exceptions to this general indictment are Gil 1969, Glacken 1967, Laín Entralgo 1970, Lovejoy [1936] 1976, Mayr 1982, Onians [1951] 1973, and Wooster [1977] 1979.

2. For a masterful discussion of these issues, see Laín Entralgo I96r. A useful collection on this subject is Caplan, Engelhardt, and McCartney, eds., I98I.

\section{Evolving Natural Categories: Darwin's Unique Legacy}

r. Darwin's books, letters, and notebooks are the place to begin; the secondary scholarship should be read against a thorough knowledge of Darwin's own writings. Among reviews and interpretations of Darwin, I found Eiseley 1958, Ghiselin 1969, Hull, comp. I973, Hyman 1962, Irvine 1956, Manier I978 particularly interesting. Gruber's publication of and commentary on Darwin's notebooks (1974) make an invaluable contribution to our understanding of the development of Darwin's thought.

Allen 1975 provides a brief summary of the post-Darwinian modifications and developments of the theory of evolution. Hull 1974 and Beckner 1968 provide useful analytical insights into the structure and formal requirements of evolutionary theory. R. Smith 1972 gives a brief and extremely clear portrait of Wallace's views.

On contemporary issues of major importance in the development of evolutionary theory there is an immense amount of commentary. Here I list only those I found directly useful in preparation of this work. On the phenotype/ genotype distinction and associated analytical problems, Lewontin 1974 and [1974] 1976 are superb.

Regarding the problems of units and species in evolution, in addition to Beckner I968, Simpson [1949] I965 and Mayr 1963 are very helpful. On the questions of the constancy of rates of selection and evolution, Williams 1966 and Gould 1977 are thought-provoking.

The critique of theories of optimization in evolution is carried forward convincingly in Lewontin 1978 and Gould and Lewontin 1979.

Nearly all of the works mentioned so far deal in one way or another with the problem of teleology and advance in evolution. Specific discussions of these problems are found in Mayr 1976 and Slobodkin 1977.

2. This is hardly a novel assertion about evolutionism. Yet as Ernest Mayr has recently pointed out ( 1982 ), the full implications of this reorientation have not been sufficiently appreciated. Mayr's contrast between "essentialist" and "population" thinking captures the fundamental distinction between evolutionary and pre- or nonevolutionary views. Mayr also recognizes the persistence of essentialist thinking as a dilemma in the modern biological sciences.

Though Mayr has succeeded in pointing out that the very core of evolution- 
ism is a revised attitude toward classification, he remains puzzled by the persistence of essentialist views in modern biology. This puzzlement leads him to explore religious and other such factors that may impinge on biological thinking and thus account for the problem. This analytical approach to the problem is not adequate; it leaves key cultural issues untouched.

3. Douglas 1966, I973; Leach 1958, 1964, 1976; Lévi-Strauss 1962 and Schneider I 968 are representative of a much larger literature.

4. While the anthropological literature on classification is enormous, the specific relationship between classification and morality has not received sufficient explicit attention.

\section{Part II Simple Continuities}

\section{Humoral Politics: Races, Constitutional Types, and Ethnic and National Character}

I. See Bateson 1979; Birdwhistell 1972; Blacking, ed., 1977.

2. See Haley 1978 and Sontag $1977-78$, among many other examples.

3. See Gibson, ed., I97 I for a superb collection of texts on this subject.

\section{Part III Complex Continuities}

I. A major exception of this stricture is Stephen Jay Gould's superb contextualization of Cyril Burtt (198I).

2. Both examples are drawn from Spanish sources. They are based on my own research and reflect my interest in the historical anthropology of Spain. Though it might seem that the choice of Spanish examples limits the generalizability of the results of my analysis, I do not think it does. At this level of generality, the Spanish case is indistinguishable from other European examples. The system of nobility in Spain was typical of Europe during the period, and the views of Spanish Enlightenment thinkers are virtually indistinguishable from those of their European contemporaries. All historical cases are unique, but nothing in the materials used in Chapters 4 and 5 could not be said on the basis of materials from other European countries.

\section{Purity of Blood and Social Hierarchy}

A version of this chapter was presented to the combined colloquium of the West European Studies Program and the Department of Anthropology at Indiana University. My thanks to Jerome Mintz for the invitation. It was subsequently published in Spanish in an indescribably mutilated form (Greenwood I978). I thank Steven Kaplan, Bernd Lambert, Edmund Leach, and Dennis MacGilvary for their commentaries and suggestions for revision. James 
Boon provided useful bibliographic suggestions. My initiation into the handling of these documents was provided by Julio Caro Baroja.

r. A useful discussion of these ideas is found in Onians [195I] 1973. Through analysis and comparison of multiple texts, Onians develops a portrait of Greek and Roman views on these subjects.

2. See, for example, Sabuco 1587 .

3. I have written about Basque ideas on collective nobility at length elsewhere, specifically in relation to Basque ethnogenesis (Greenwood 1976a, 1977). More of the historical details can be found there. The specifics of this discussion will be limited to Guipúzcoa in order to make use of a single set of legal codes. Similar arguments can be made for Vizcaya and for parts of Alava and $\mathrm{Na}$ varra.

4. All translations are mine.

\section{An Enlightenment Humoralist: Don Diego de Torres Villarroel}

I. This point was made to me by Pilar Fernández-Cañadas de Greenwood and has been elaborated in her forthcoming paper "Los médicos del "Canto de Calíope."”

2. The works that have remained regularly in print are Torres Villarroel [1966] 1976 and 1972. Two others (1977 and 1979) have been republished for the first time since the 1794-99 edition of the complete works.

3. The criteria used by literary critics and historians of literature for evaluating texts differ from those of anthropologists and social historians. A text of little literary merit may be of immense anthropological value and a great work of literature can often be of little use to the social historian.

4. Partly because of the heterogeneity of subjects and literary forms and partly because of his heavyhanded satirical style, Torres has received relatively little critical attention. The most rewarding synthetic analysis of Torres' works are Granjel I 968 and Pérez' excellent introduction to Los desabuciados del mundo y de la gloria (I979). García Boiza's biography (1949) lacks critical depth. Mercadier's introduction to Vida (1972) and Sebold's introduction to Visiones $y$ visitas ... ([1966] 1976) both focus strongly on literary issues, in particular the tension in Torres between contradictory points of view. Granjel I 968 (limited to Torres' medical works) provides a good point of departure for the study of Torres.

5. All translations are mine.

6. This point is made by Valles in his introduction to Recetarios astrológicos y alquímicos (1977).

7. This was the only work by Torres to be sequestered by the Inquisition. Strangely, the action was taken long after the book's publication, and immediately afterward Vida natural was republished. 


\section{Human Sociobiology}

The central argument and some of the materials for this chapter appeared in different form in my paper "Sociobiology: From Darwinism to Moralism," Grinnell Magazine I4 (1982): I 5-19.

I. See Barnett I953.

2. See Greenwood and Stini I977, chap. 20 , for a critique. 
